
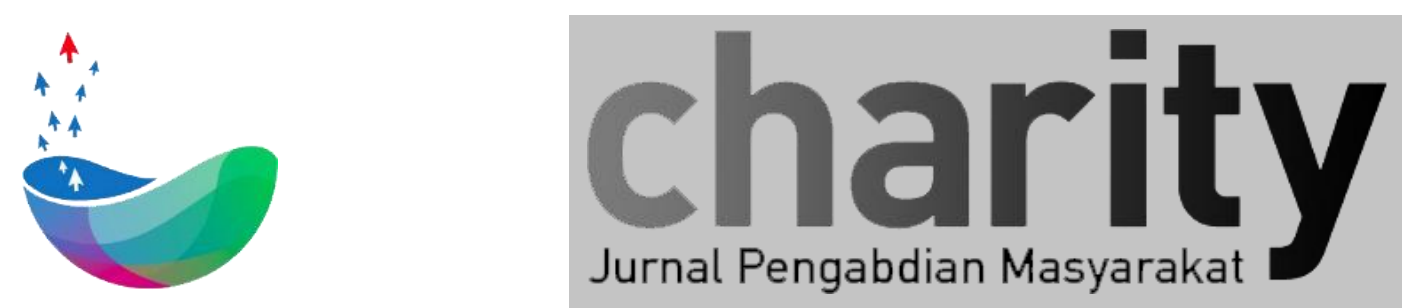

\title{
Pembangunan Aplikasi Pengembangan Konten Wisata Berbasis Komunitas di Wilayah Kabupaten Sukabumi
}

\author{
Z K A Baizal $^{1}$, Erwin Budi Setiawan ${ }^{2}$, Dede Tarwidi \\ ${ }^{1}$ Teknik Informatika, Fakultas Informatika, Universitas Telkom \\ ${ }^{2}$ Teknik Informatika, Fakultas Informatika, Universitas Telkom \\ ${ }^{3}$ Teknik Informatika, Fakultas Informatika, Universitas Telkom \\ baizal@ elkomuniversity.ac.id, ${ }^{2}$ erwin@ telkomuniversity.ac.id, ${ }^{3}$ dede @ telkomuniversity.ac.id
}

\section{INFO ARTIKEL}

Diterima 28 November 2019

Direvisi 12 Juli 2020

Disetujui 27 Agustus 2020

Tersedia Online 28 Agustus 2020

Keyword: smart tourism, komunitas penggiat wisata, media sosial, wisata sukabumi, telkom university

\begin{abstract}
ABSTRAK
Pariwisata merupakan salah satu industri yang menjadi andalan sebuah daerah. Kabupaten Sukabumi mempunyai potensi besar dalam hal pariwisata yang dapat menunjang pendapatan daerah. Beberapa tempat wisata di wilayah Kab Sukabumi antara lain [1], [2] : Danau Bacan, Bukit Karang Pra, Geopark Ciletuh, Tebing Panenjoan, Bravo adventure, Kampung Ciptagelar, dsb. Saat ini telah banyak berkembang aplikasi-aplikasi media sosial, dimana kontennya dikembangkan oleh pengguna sendiri. Konten dari media sosial ini berkembang begitu cepat, karena pada dasarnya konten tidak dikembangkan secara centralized, namun decentralized. Konten dalam Wikipedia misalnya. Semua pengguna dapat memperkaya konten Wikipedia, sehingga pengayaan konten dapat berkembang cepat, dan pihak Wikipedia bertugas mengkontrol konten tersebut. Contoh contoh yang lain seperti facebook, Instagram, bahkan website (apilkasi) e-commerce-pun, pengeyaan konten berbasis pengguna. Konsep ini tentu akan lebih bermanfaat jika dapat diterapkan juga pada aplikasi (website), dimana kontennya dikembangkan oleh pengguna aplikasi, atau dapat disebut sebagai komunitas. Komunitas ini dapat berupa komunitaskomunitas penggiat wisata, kesenian, kerajinan di daerah kabupaten Sukabumi. Komunitas dapat juga berarti para wisatawan itu sendiri maupun masyarakat yang peduli dengan potensi wisata di Sukabumi. Setiap pengguna (komunitas) dapat menambahkan tempat wisata, deskripsi, foto-foto, video, dan juga review dan rating dalam aplikasi. Untuk program pengabdian masyarakat kali ini, tim Telkom University bekerjasama dengan Grup Wisata Alam Sukabumi sebagai mitra, yang nantinya dapat menjadi pemilik aplikasi yang tim kembangkan sekaligus sebagai pengelola aplikasi. Dengan demikian, pihak mitra mendapatkan keuntungan dengan mendapatkan datadata wisata baru untuk memperkaya database wisata, juga mendapatkan feedback terhadap layanan wisata dari review dan rating para pengguna. Feedback ini dapat dimanfaatkan untuk evaluasi dan monitoring, untuk
\end{abstract}


pengembangan layanan wisata yang lebih baik. Dalam pengembangan ini, kami menggandeng ahli dari Universiti Tun Hussein Onn Malaysia (UTHM), Dr. Mohd Rasidi Bin Ibrahim Seorang ahli dalam bidang Industri dan Teknologi Informasi Sebagai rekanan dalam pengembangan aplikasi ini.

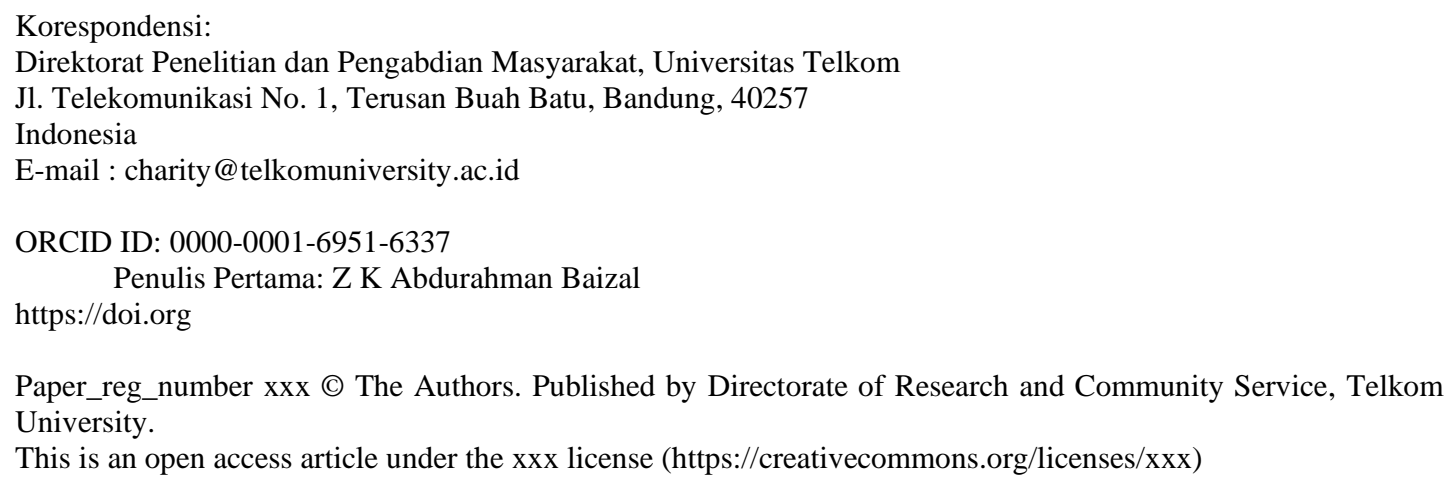

\section{Pendahuluan}

Kabupaten Sukabumi merupakan kabupaten terluas kedua di Pulau Jawa setelah Kabupaten Banyuwangi di Provinsi Jawa Timur. Kabupaten ini berbatasan dengan Kabupaten Bogor di utara, Kabupaten Cianjur di timur, Samudra Hindia di selatan, serta Kabupaten Lebak di barat. Pada awalnya daerah Kabupaten Sukabumi saat ini ada dibawah Kabupaten Cianjur pada masa Pemerintahan kolonial Hindia Belanda, yang merupakan bagian dari Karesidenan Priangan (Residentie Preanger Regentschappen). Pada tahun 1776 Bupati Cianjur keenam Raden Noh Wiratanudatar VI membentuk sebuah kepatihan bernama Kepatihan Tjikole. Di tanggal 13 Januari 1815, Kepatihan Tjikole berganti nama menjadi Kepatihan Soekaboemi.

Kabupaten Sukabumi merupakan salah satu daerah di Jawa Barat yang mempunyai potensi wisata yang besar. Beberapa tempat wisata yang terkenal diantaranya : Pelabuhan Ratu, Pantai Sukawana, Danau Bacan, Bukit Karang Pra, Geopark Ciletuh, Tebing Panenjoan, Bravo adventure, Kampung Ciptagelar (Gambar 1), dsb. Geopark Ciletuh sendiri merupakan suatu tempat wisata yang saat ini sedang booming, karena tempat ini mempunyai beberapa destinasi yang sangat menarik, seperti Curug Cigangsa, Curug Awang, Curug Cikaso, Curug Cimarinjung, dsb. 


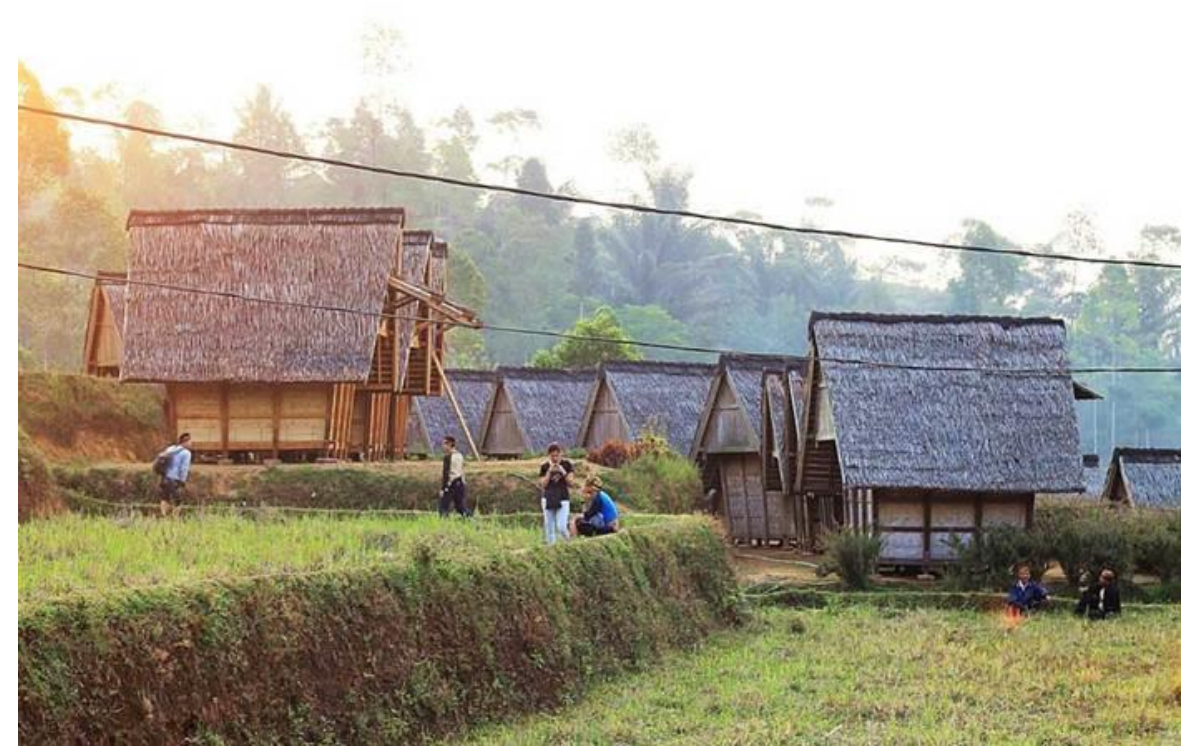

Gambar 1. Kampung Ciptagelar, Sukabumi

Besarnya potensi wisata di wilayah Kab Sukabumi ini memunculkan keinginan Grup Wisata Alam Sukabumi (mitra) untuk membangun sebuah sarana informasi yang selengkap-lengkapnya tentang pariwisata di wilayah ini. Sarana informasi yang memuat konten destinasi wisata yang sudah cukup banyak dikenal, akan mendongkrak destinasi-destinasi wisata lain yang belum dikenal, jika semua informasi tersebut terintegrasi dalam sebuah portal pariwisata. Informasi pariwisata meliputi destinasi pariwisata, tempat menginap, serta produk atau jasa layanan yang ditawarkan di Kabupaten Sukabumi.

Banyaknya tempat wisata di Sukabumi ini harus dibarengi dengan pengayaan konten dalam website (aplikasi) yang official dari Grup Wisata Alam Sukabumi (mitra). Belum adanya database tempat wisata yang komprehensif di Sukabumi merupakan salah satu permasalahan saat ini. Pihak Grup Wisata Alam Sukabumi (mitra) juga membutuhkkan feedback atau tanggapan dari masyarakat tentang destinasi-destinasi wisata di wilayah Sukabumi, sebagai masukan untuk pengembangan layanan wisata ke depan.

Saat ini, teknologi yang memanfaatkan internet merupakan salah satu cara yang paling efektif dan efisien yang digunakan untuk melakukan promosi wisata. Berkembangnya konten dengan pesat dalam media social dapat menjadi inspirasi untuk pengayaan konten wisata dalam apliksi wisata Kab Sukabumi. Dalam program pengabdian masyarakat ini, Tim pengabdian masyarakat dari Telkom University dengan bekerjasama dengan grup wisata alam sukabumi serta tim pengabdian masyarakat dari Universiti Tun Hussein Onn Malaysia (UTHM)

membuat sebuah aplikasi, dimana komunitas-komunitas dalam maysarakat dapat ikut berperan aktif dalam mengembangkan konten wisata di Sukabumi. Komunitas, dalam hal ini sebagai pengguna aplikasi, mempunyai kesempatan 
untuk menambahkan konten berupa tempat wisata, deskripsi, foto-foto, video, review, dan rating terkait kepatiwisataan di Sukabumi. Hal ini juga dibarengi dengan berkembangnya komunitas-komunitas penggiat wisata di wilayah Sukabumi. Komunitas ini mengelola tempat-tempat wisata yang ada di Sukabumi. Hal ini tentu sangat menguntungkan untuk mempercepat berkembangnya potensi wisata. Dengan pengembangan konten berbasis komunitas ini, komunitas diuntungkan karena dapat mempromosikan tempat wisata yang dikelola, wisatawan juga diuntungkan dengan adanya informasi lengkap tentang wisata termasuk review dan rating-nya. Grup Wisata Alam Sukabumi (mitra) juga diuntungkan dalam hal pengayaan database wisata, serta mendapatkan feedback tentang layanan wisata, untuk pengembangan lebih lenjut ke depan. Dalam pengembangan ini, kami menggandeng ahli dari Universiti Tun Hussein Onn Malaysia (UTHM), Dr. Mohd Rasidi Bin Ibrahim Seorang ahli dalam bidang Industri dan Teknologi Informasi Sebagai rekanan dalam pengembangan aplikasi ini.

\section{Permasalahan dan Solusi yang Ditawarkan}

Semua potensi wisata baik yang sudah dikenal baik maupun yang sedang dalam pengembangan, tentunya harus diperkenalkan ke masyarakat. Hal ini menuntut adanya sarana yang menyatukan semua informasi wisata di wilayah Sukabumi. Komponen-komponen pendukung sector pariwisata meliputi: Destinasi wisata, penginapan, hotel dan tempat kuliner. Komponen komponen ini berkembang begitu cepat, seiring berkembangnya daerah Sukabumi sebagai daerah tujuan wisata. Saat ini juga komunitas penggiat wisata berkembang marak, sebagai pengelola komponen-komponen pendukung wisata ini. Sinergi yang kuat antar komunitas ini, Grup Wisata Alam Sukabumi (mitra) dan Pihak swasta sangat diperlukan, agar bersamasama dapat memajukan potensi wisata Sukabumi.

Permasalahan yang ada saat ini adalah, pihak Grup Wisata Alam Sukabumi (mitra) belum mempunyai database konten wisata yang lengkap dan komprehensif. Tentu, pengayaan konten ini akan memakan effort yang berat bagi Grup Wisata Alam Sukabumi (mitra), jika bekerja sendiri. Selain itu, di wilayah ini banyak destinasi-destinasi maupun varian dari kategori wisata yang sedang dikembangkan, dan mungkin belum dikenal masyarakat luas. Dengan adanya sarana informasi yang lengkap dan terintegrasi, destinasi-destinasi wisata tersebut dapat terdongkrak untuk lebih dikenal.

Berdasarkan analisis situasi dan permasalahan mitra yang diungkapkan sebelumnya, kami menawarkan solusi dengan membangun sebuah aplikasi wisata dengan pengembangan konten berbasis komunitas. Pengembangan aplikasi ini terinspirasi oleh berkembang pesatnya media-media social saat ini. Dalam media social tersebut, konten berkembang begitu cepat. Setiap pengguna mempunyai otoritas untuk menambahkan konten. Dalam situs pengetahuan seperti Wikipedia, konten juga dikembangkan oleh pengguna. Dalam situs-situ e-commerce, konten juga diperkaya oleh pengguna. Dengan demikian, pengayaan konten tidak bersifat centralized, namun bersifat 
decentralized. Pengayaan konten secara desentralized ini tentu akan mempercepat pengayaan konten. Hal ini didukung dengan berkembang maraknya komponen-komponen pendukung wisata yang dikelola oleh komunitas penggiat wisata, oleh swasta maupun oleh pemerintah sendiri. Setiap pengguna, dimana pengguna dapat berupa komunitas pengguna wisata, wisatawan maupun masyarakat pemerduli wisata diberi kesempatan untuk memperkaya konten dari masing-masing komponen wisata. Komponen pendukung wisata ini berupa destinasi wisata, penginapan atau hotel, tempat kuliner, event budaya, kerajinan dsb. Setiap pengguna aplikasi dapat menambahakan komponen-komponen baru, mengedit dari komponenkomponen yang sudah ada, memberikan review atau kesan, serta memberi rating terhadap salah satu atau beberapa komponen wisata ini.

\section{Metode Pelaksanaan}

Tahapan pelaksanaan pengabdian masyarakat ini adalah

1. Analisis terhadap kebutuhan dari mitra, terkait pengembangan pariwisata saat ini dan harapan yang akan dicapai di masa depan Mitra merupakan sebuah Komunitas penggiat wisata di daerah Sukabumi yang bernama Grup Wisata Alam Sukabumi. Aplikasi yang dibuat harus mampu menjawab beberapa permasalahan dan juga kebutuhan terkait pengembangan pariwisata di wilayah Sukabumi. Dari kebutuhankebutuhan mitra dianalisis untuk diberikan solusi dalam bentuk suatu aplikasi pengembangan konten pariwisata berbasis komunitas.

2. Pengembangan aplikasi pengembangan konten berbasis komunitas Aplikasi dibangun dengan berbasis web, dimana setiap pengguna diberi otoritas untuk menambahkan komponen wisata, mengedit komponen wisata yang sudah ada. Selain itu, pengguna juga dapat memberikan review dan rating untuk suatu komponen pendukung wisata. Pihak Pengelola Aplikasi mempunyai otoritas untuk menambah mengedit, menghapus dan juga approvement terhadap konten-konten baru. Aplikasi berbasis web ini diusahakan familiar dengan perangkat mobile.

3. Pelatihan admin/komunitas penggiat wisata Pelatihan tentang penggunaan aplikasi perlu dilakukan, baik untuk tenaga admin maupun komunitas-komunitas penggiat wisata di Kab Sukabumi. Diharapkan, pihak mitra (Grup Wisata Alam Sukabumi) dapat mengkoordinasi komunitas-komunitas ini dalam pelaksanaan pelatihan sekaligus penyuluhan. 


\section{Hasil dan Pembahasan}

\subsection{Aplikasi yang Telah Dikembangkan}

Dengan aplikasi ini, para penggiat pariwisata, para pengelola destinasi wisata, seperti penginapan, tempat makan, dan tempat wisata dapat menambahkan konten, mengedit konten pariwisata tersebut. Selain itu, wisatawan dapat meberikan komentar tentang destinasi wisata yang telah dikunjungi serta merating dengan mendaftar dulu sebagai member. Manfaat lain adalah para calon wisatawan dapat melihat komentar-komentar tersebut untuk memutuskan tempat wisata mana yang akan dikunjungi. Aplikasi ini dapat diakses dari www.pesonasukabumi.com. 

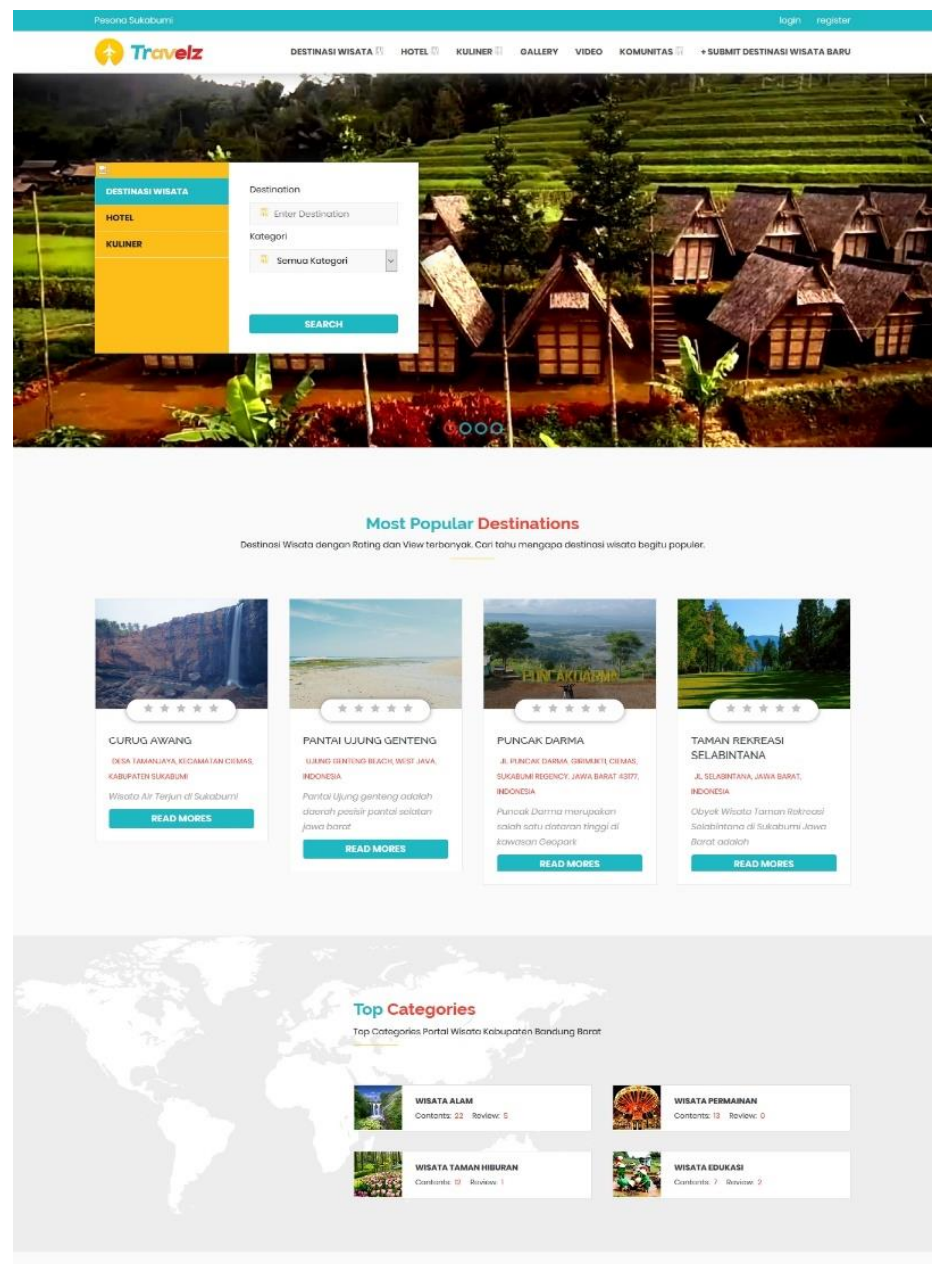

Lastest Articles
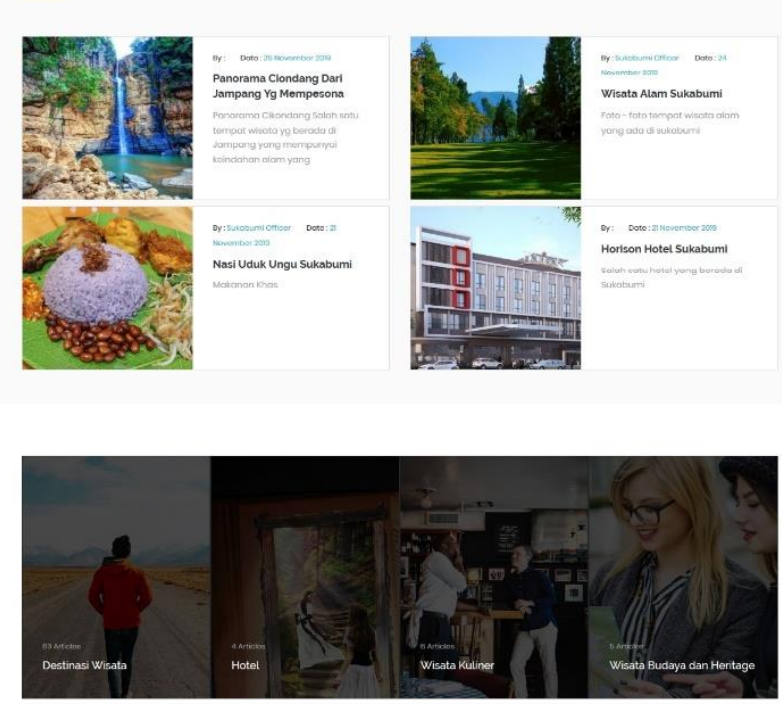

\section{(A) Travelz}

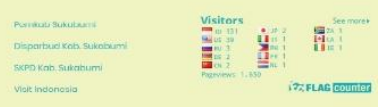

Gambar 1. Halaman awal aplikasi smart-travelling di www.pesonasukabumi.com 


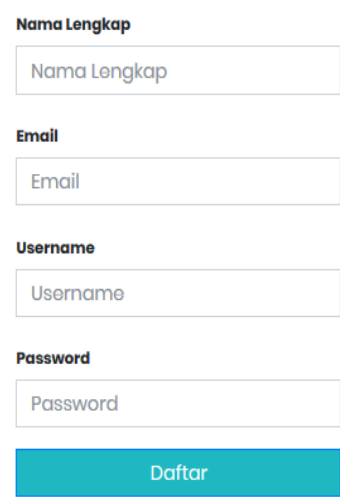

Q. LOGIN

Sudah memiliki akun? Login sekarang

- LUPA PASSWORD

Klik disini jika anda Lupa Password anda

Mari menjadi bagian dari -

Dengan Klik Daftar, Agan telah menyetujui Syarat $\&$

Ketentuan serta Kebijakan Privasi

Gambar 3. Halaman Registrasi Member

\section{Username or Email}

Username or Email

\section{Password}

Password

$\square$ Remember me
Q. DAFTAR SEKARANG

Belum mempunyai akun? Sillahkan daftar sekarang

- LUPA PASSWORD

Klik disini jika anda Lupa Password

Dengan kilik Login, Agan telah menyetujui Syarat \&

Ketentuan serta Kebijakan Privasi.

Gambar 4. Halaman Login Member

Pada halaman awal, disajikan pengguna dapat melakukan searching tempat wisata, maupun dapat meminta untuk ditampilkan tempat wisata berdasarkan kategorinya. Selain itu, sistem memberikan rekomendasi tempat pariwisata bagi pengguna berdasarkan tempat wisata yang paling favorit, kategori wisata yang paling favorit maupun tempat-tempat wisata yang baru saja dibuka oleh pengguna-pengguna yang lain. 


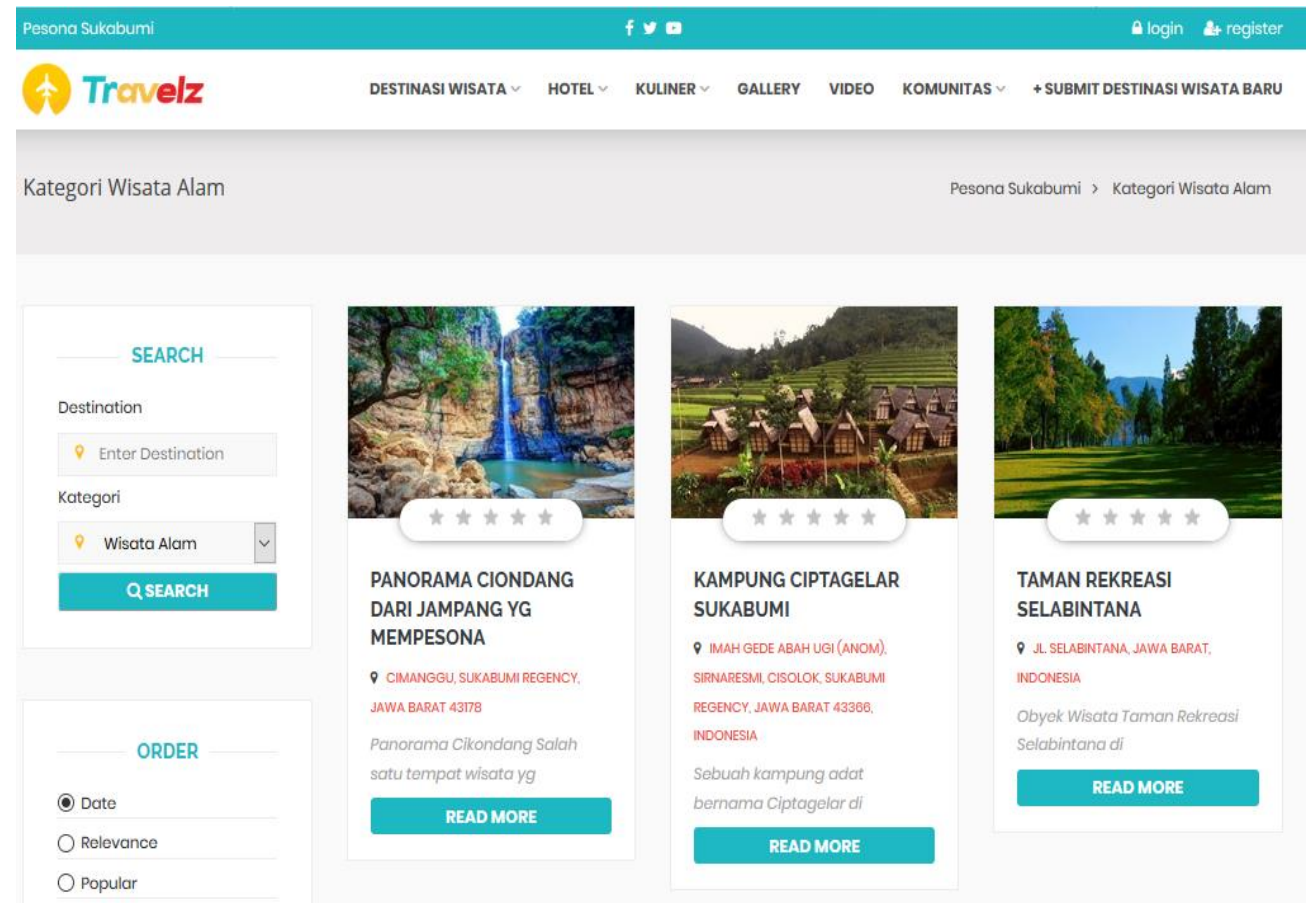

Gambar 5. Tempat-tempat Wisata Alam

Tempat-tempat wisata yang disajikan pada Gambar 5, dapat ditampilkan berdasarkan beberapa kriteria, seperti berdasarkan tanggal, relevansi, popularitas, rating dan yang paling banyak direview. Pengguna juga dapat memasukan tempat wisata baru, tentunya dengan mendaftar dulu sebagai Komunitas dan login Sebagai Komunitas terlebih dahulu, seperti pada Gambar 6 dan Gambar 7.

\begin{tabular}{|l|l|l|}
\hline Nama Komunitas \\
\hline Alamat Komunitas \\
\hline Nama Admin Komunitas & \\
\hline Alamat Email & Nomor KTP \\
\hline Username & \\
\hline & \\
\hline
\end{tabular}

Gambar 6. Halaman Registrasi Komunitas 


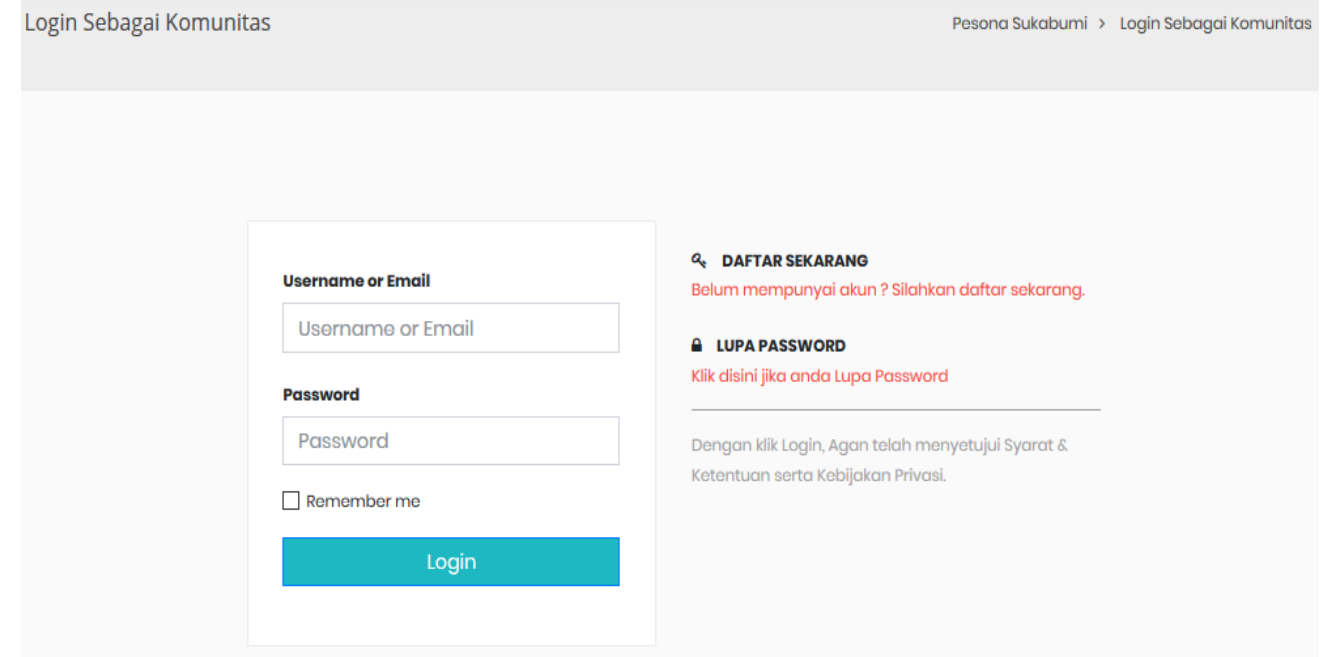

Gambar 7. Halaman Login Komunitas 


\subsection{Koordinasi dan Pelatihan}

Koordinasi dan pelatihan dilaksanakan langsung dengan owner website pesonasukabumi.com yaitu Bapak Hidayat Asep.

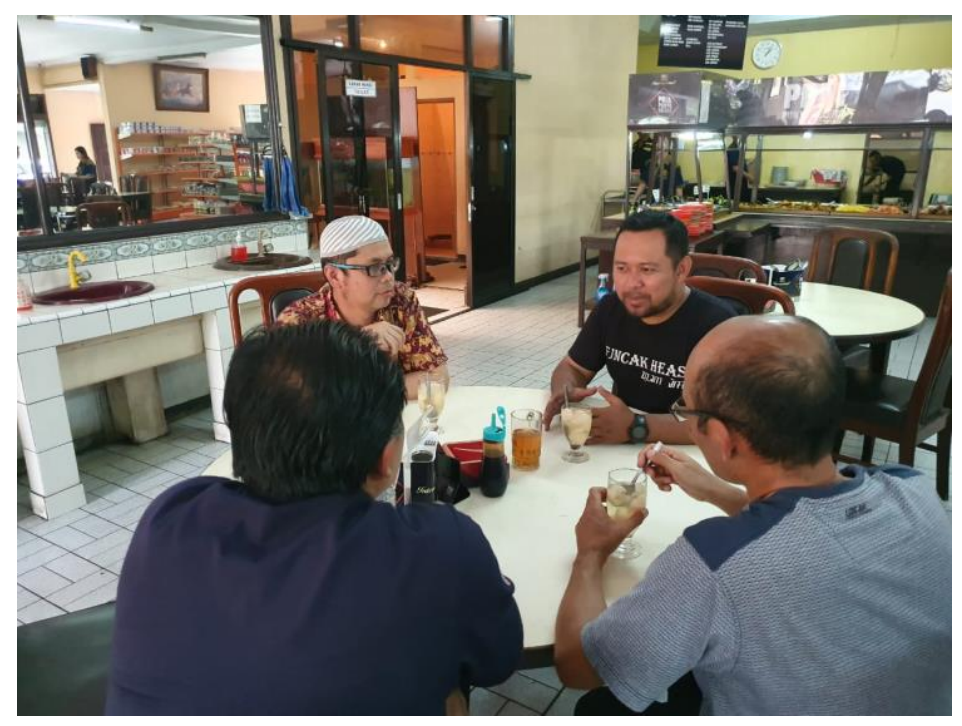

Gambar 8. Koordinasi dan Pelatihan 1

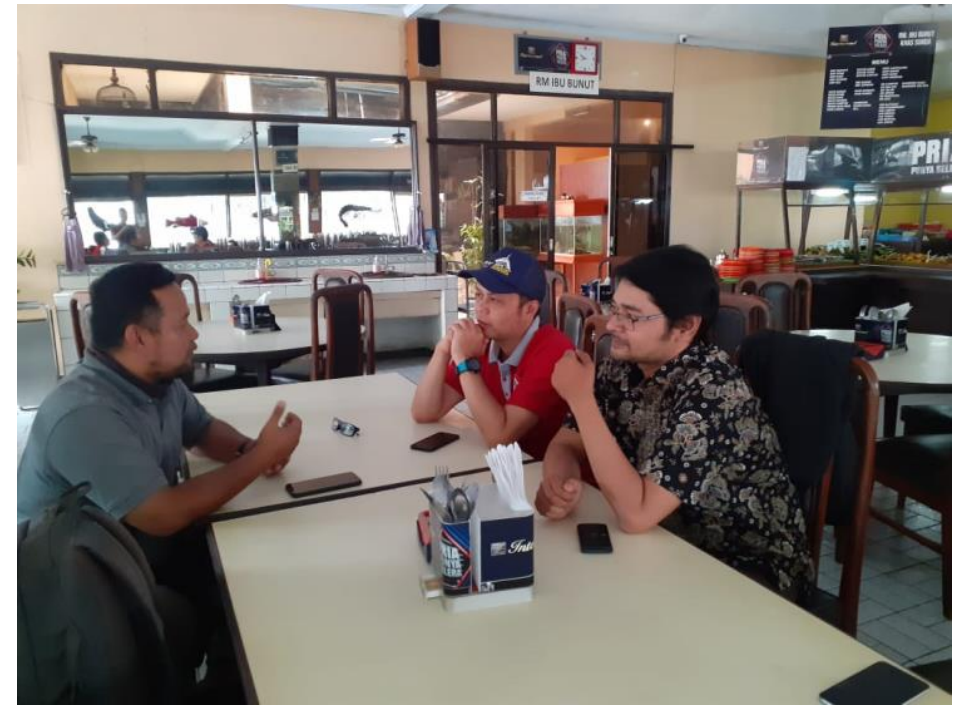

Gambar 9. Koordinasi dan Pelatihan 2 


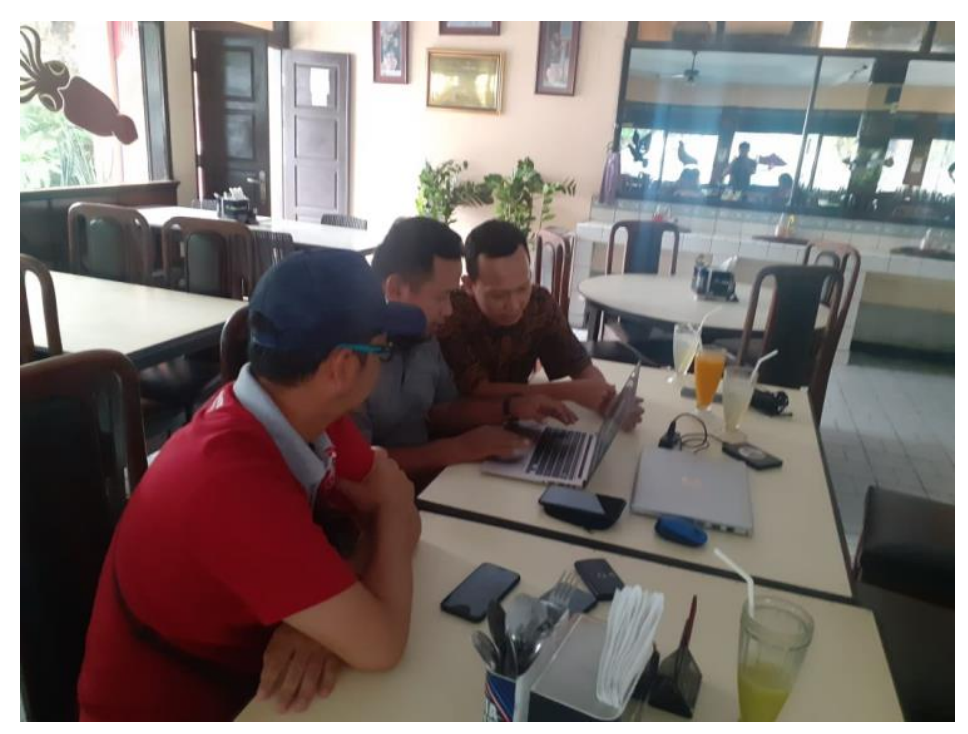

Gambar 10. Koordinasi dan Pelatihan 3

\section{Kesimpulan}

Saat ini telah banyak tempat-tempat wisata baru yang muncul di daerah Sukabumi. Destinasi Wisata ini banyak dikelola oleh Komunitas Penggiat Wisata. Dari disukusi yang telah dilakukan antara tim Abdimas dan Mitra dapat diperoleh kesimpulan bahwa informasi wisata di daerah Sukabumi, terutama tempat-tempat wisata baru yang sedang tumbuh perlu ditingkatkan. Diharapkan, aplikasi wisata pesonasukabumi.com yang kami kembangkan dapat menyampaikan informasi ini dengan lebih baik. Effort dari pengelola aplikasi dalam mengupdate konten wisata dapat diminimalkan, karena pengayaan konten wisata dapat dilakukan oleh Komunitas pengelola wisata. Komunitas pengelola wisata juga diuntungkan, karena dapat mempromosikan destinasi wisata yang mereka kelola di pesonasukabumi.com. Masyarakat juga diuntungkan dengan adanya informasi wisata yang lebih komprehensif. Wisatawan juga dapat memberikan komentar dan rating untuk setipa destinasi wisata yang sudah pernah dikunjungi.

\section{DAFTAR PUSTAKA}

[1] Darsiharjo, D. (2016). Pengembangan Geopark Ciletuh berbasis partisipasi masyarakat sebagai kawasan geowisata di kabupaten Sukabumi. Jurnal Manajemen Resort dan Leisure, 13(1). 
[2] Hijriati, E., \& Mardiana, R. (2014). Pengaruh ekowisata berbasis masyarakat terhadap perubahan kondisi ekologi, sosial dan ekonomi di Kampung Batusuhunan, Sukabumi. Jurnal Sosiologi Pedesaan, 2(3), 146-159. 